\title{
Body Weight Measurement
}

National Cancer Institute

\section{Source}

National Cancer Institute. Body Weight Measurement. NCI Thesaurus. Code C92648.

A measurement of the body weight of a subject. 